\title{
Mineral Resources of the Browns Canyon Wilderness Study Area, Chaffee County, Colorado
}
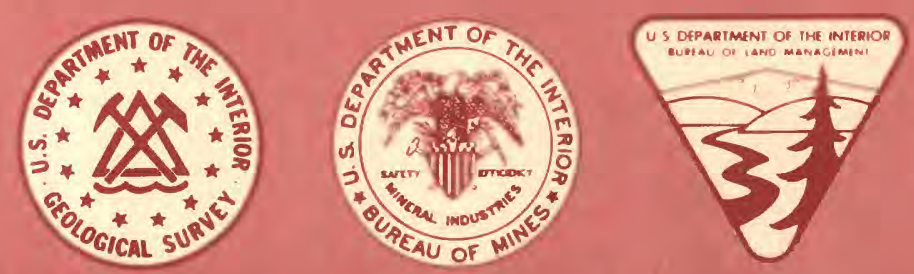

\section{U.S. GEOLOGICAL SURVEY BULLETIN 1716-C}

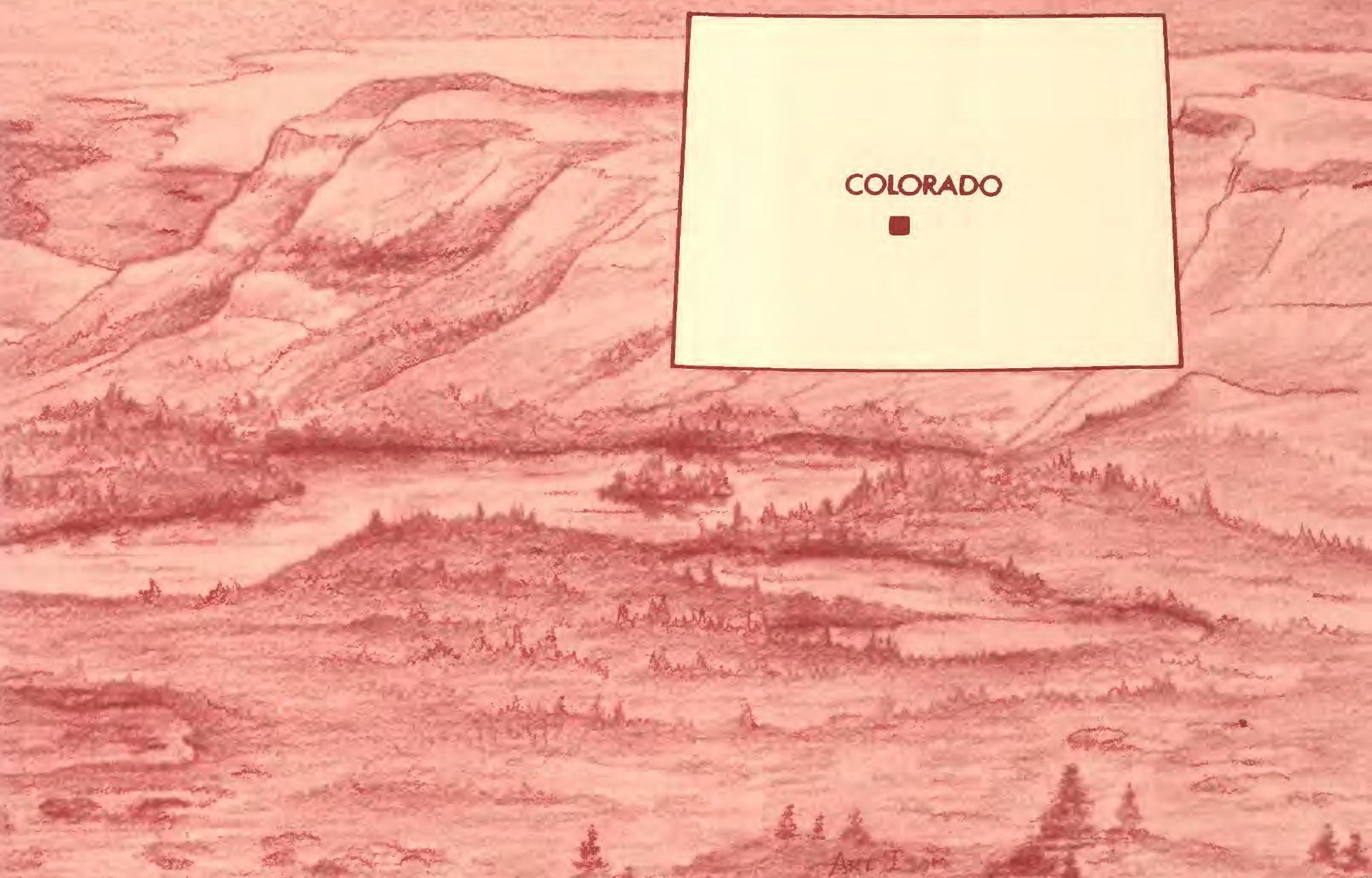




\section{DEFINITION OF LEVELS OF MINERAL RESOURCE POTENTIAL AND CERTAINTY OF ASSESSMENT}

\section{Definitions of Mineral Resource Potential}

LOW mineral resource potential is assigned to areas where geologic, geochemical, and geophysical characteristics define a geologic environment in which the existence of resources is unlikely. This broad category embraces areas with dispersed but insignificantly mineralized rock as well as areas with few or no indications of having been mineralized.

MODERATE mineral resource potential is assigned to areas where geologic, geochemical, and geophysical characteristics indicate a geologic environment favorable for resource occurrence, where inteipretations of data indicate a reasonable likelihood of resource accumulation, and (or) where an application of mineral-deposit models indicates favorable ground for the specified type(s) of deposits.

HIGH mineral resource potential is assigned to areas where geologic, geochemical, and geophysical characteristics indicate a geologic environment favorable for resource occurrence, where interpretations of data indicate a high degree of likelihood for resource accumulation, where data suppor mineral-deposit models indicating presence of resources, and where evidence indicates that mineral concentration has taken place. Assignment of high resource potential to an area requires some positive knowledge that mineral-forming processes have been active in at least part of the area.

UNKNOWN mineral resource potential is assigned to areas where information is inadequate to assign low, moderate, or high levels of resource potential.

NO mineral resource potential is a category reserved for a specific type of resource in a well-defined area.

\section{Levels of Certainty}

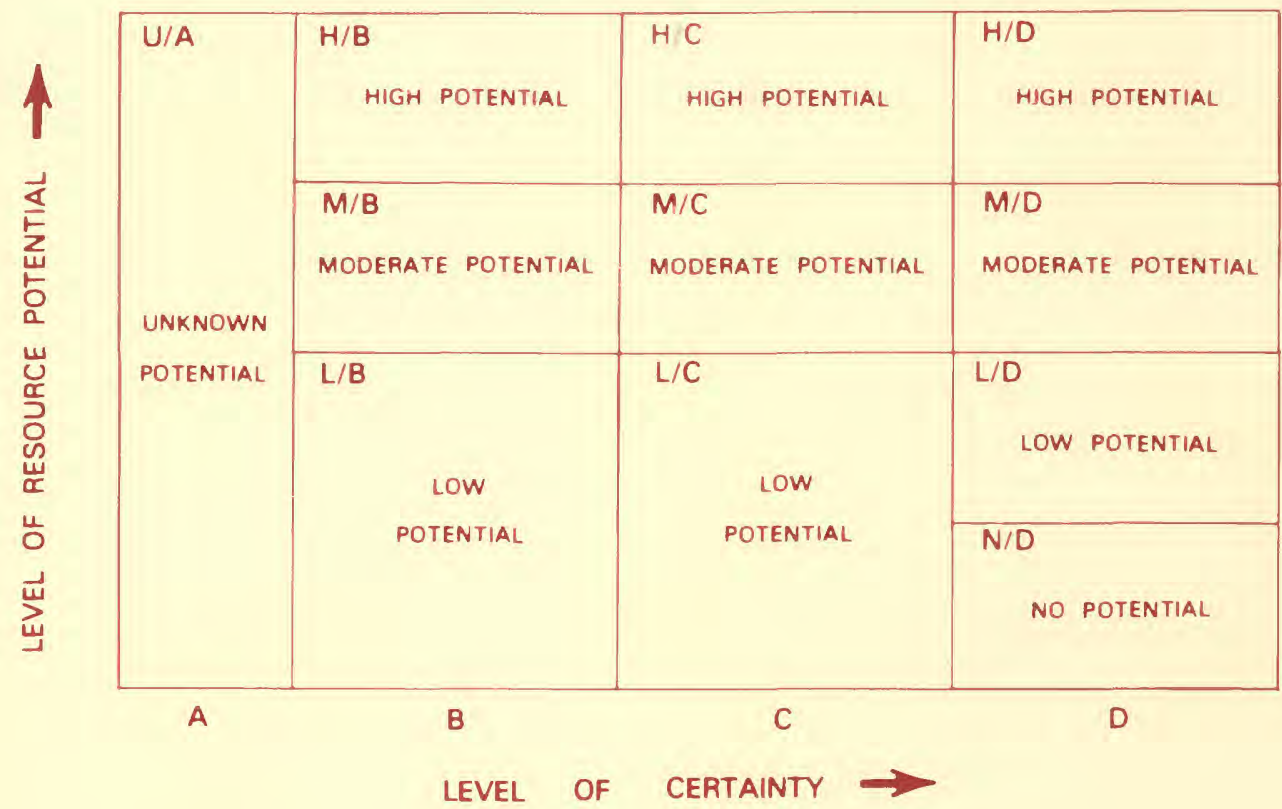

A. Available information is not adequate for determination of the level of mineral resource potential.

B. Available information suggests the level of mineral resource potential.

C. Available information gives a gond indication of the level of mineral resource potential.

D. Available information clearly defines the level of mineral resource potential.

\section{Abstracted with minor modifications from:}

Taylor, R. B., and Steven, T. A.. 1983, Definition of mineral resource potential: Economic Geology, v. 78 , no. 6, p. $1268-1270$.

Taylor. R. B.. Stoneman, R. J.. and Marsh. S. P.. 1984. An assessment of the mineral resource potential of the San Isabel National Forest, south-central Colorado: U.S. Geological Survey Bulletin 1638, p. $40-42$.

Goudarzi. G. H., compiler, 1984. Guide to preparation of mineral survey reports on public lands: U.S Geological Survey Open-File Report 840787 . p. 7.8. 
Chapter C

MINERAL RESOURCES OF WILDERNESS STUDY AREASSOUTH-CENTRAL COLORADO

\section{Mineral Resources of the Browns Canyon Wilderness Study Area, Chaffee County, Colorado}

By Anne M. Leibold, Ronald G. Worl, and Ronny A. Martin, U.S. Geological Survey, and Jeanne E. Zelten, U.S. Bureau of Mines 


\section{DEPARTMENT OF THE INTERIOR DONALD PAUL HODEL, Secretary}

\section{U.S. GEOLOGICAL SURVEY Dallas L. Peck, Director}

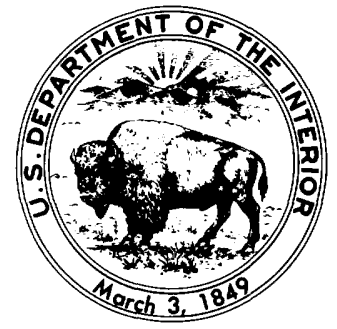

For sale by the Branch of Distribution

Books and Open-File Reports Section

U.S. Geological Survey

Federal Center

Box 25425

Denver, CO 80225

Library of Congress Cataloging in Publication Data

Mineral resources of the Browns Canyon Wilderness Study Area, Chaffee County, Colorado.

(Mineral resources of wilderness study areas-South-Central Colorado; ch. C) (U.S. Geological Survey bulletin ; 1716-C)

Bibliography: $p$.

Supt. of Docs. No.: | 19.3:1716-C

1. Mines and mineral resources-Colorado-Browns Canyon

Wilderness. 2. Geology-Colorado-Browns Canyon Wilderness. 3.

Browns Canyon Wilderness (Colo.)

I. Leibold, Anne M. II. Series. III. Series: U.S. Geological Survey bulletin : 1716-C. 


\section{STUDIES RELATED TO WILDERNESS}

\section{Bureau of Land Management Wilderness Study Areas}

The Federal Land Policy and Management Act (Public Law 94-579, October 21, 1976) requires the U.S. Geological Survey and the U.S. Bureau of Mines to conduct mineral surveys on certain areas to determine the mineral values, if any, that may be present. Results must be made available to the public and be submitted to the President and the Congress. This report presents the results of a mineral survey of the Browns Canyon (CO-050-002) Wilderness Study Area, Chaffee County, Colorado. 


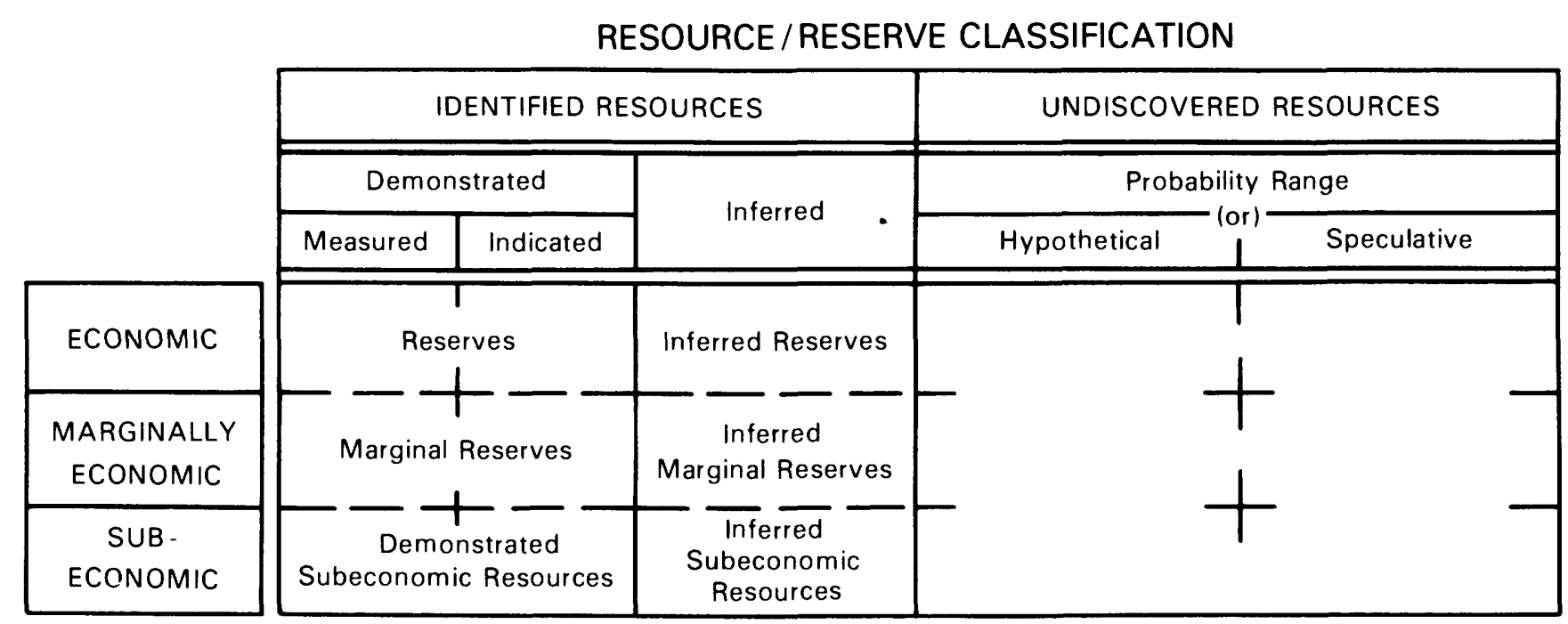

- Major elements of mineral resource classification, excluding reserve base and inferred reserve base. Modified from U. S. Bureau of Mines and U. S. Geological Survey, 1980, Principles of a resource/reserve classification for minerals: U. S. Geological Survey Circular 831, p. 5. 


\title{
CONTENTS
}

\author{
Summary 1 \\ Introduction $\mathbf{3}$ \\ Investigation by the U.S. Bureau of Mines 3 \\ Investigation by the U.S. Geological Survey 4 \\ Appraisal of identified resources 4 \\ Mining and mineral-exploration activity 4 \\ Geothermal resources 5 \\ Oil and gas 5 \\ Appraisal of sites examined 5 \\ Perlite and associated rocks 5 \\ Ruby Mountain deposit $\mathbf{5}$ \\ Cottonwood Creek deposit 7 \\ Rock and mineral specimens 7 \\ Sand and gravel 7 \\ Assessment of potential for undiscovered resources $\mathbf{8}$ \\ Geology 8 \\ Geologic setting 8 \\ Description of rock units \\ Geochemistry 9 \\ Analytical methods 9 \\ Results of survey 9 \\ Geophysics 10 \\ Mineral and energy resources 10 \\ References cited 13
}

PLATE

(In pocket)

1. Map showing mineral resource potential, geology, and geochemical sample localities of the Browns Canyon Wilderness Study Area

\section{FIGURES}

1. Map showing mineral resource potential and generalized geology of the Browns Canyon Wilderness Study Area 2

2. Index map showing the location of the Browns Canyon Wilderness Study Area 3

3. Map showing oil and gas lease application and Browns Canyon thermal area near the Browns Canyon Wilderness Study Area 6

4. Aeromagnetic contour map of the Browns Canyon Wilderness Study Area 11

5. Gravity contour map of the Browns Canyon Wilderness Study Area 12 


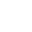




\title{
Mineral Resources of the Browns Canyon Wilderness Study Area, Chaffee County, Colorado
}

\author{
By Anne M. Leibold, Ronald G. Worl, and Ronny A. Martin \\ U.S. Geological Survey and \\ Jeanne E. Zelten \\ U.S. Bureau of Mines
}

\section{SUMMARY}

In 1983 and 1984 the U.S. Geological Survey and the U.S. Bureau of Mines conducted studies to appraise the identified mineral resources and assess the mineral resource potential of the Browns Canyon Wilderness Study Area (CO-050-002). There are no mines and few prospects in the study area. Small perlite deposits are present in the study area, but it is not feasible to develop them economically at this time. Geological, geochemical, and geophysical studies indicate low potential for undiscovered mineral resources, including geothermal resources and oil and gas (fig. 1).

The Browns Canyon Wilderness Study Area consists of 6,614 acres of rugged, mountainous terrain on the eastern edge of the Arkansas River valley, about $6 \mathrm{mi}$ (miles) southeast of Buena Vista and 7 mi northwest of Salida, in Chaffee County, Colorado. Early Proterozoic (1,700 m.y. or million years) metamorphic and igneous rocks and Oligocene and Miocene (38-12 m.y.) volcanic rocks underlie the study area. Oligocene, Miocene, and Pliocene (38-3 m.y.) volcanic and sedimentary rocks are exposed nearby.

Between 1927 and 1949, about 130,000 tons of fluorspar were recovered from the Browns Canyon fluorspar district, less than $1 \mathrm{mi}$ southwest of the study area (fig. 1) (Van Alstine, 1969). The fault zone along which the fluorite occurs trends northwest and does not extend into the study area. Gold, silver, copper, lead, zinc, iron, and pegmatite minerals were mined from the Turret mining district, centered about $2 \mathrm{mi}$ east-southeast of the study area. The mineralized faults, metamorphic rocks, and zoned pegmatites present in the Turret district do not extend into the study area. Prospecting in the study area, as evidenced by pits in small quartz veins, simple pegmatites, dikes, and shear zones in granodiorite and volcanic rocks, has not revealed significant mineral deposits.

Four ounces of gold were recovered by placer mining along the western side of the Arkansas River in Browns Canyon. Warm springs are in the Browns Canyon thermal area, less than $1 \mathrm{mi}$ west of the study area. There is no surface evidence of placer mining, thermal springs, or oil and gas exploration in the study area.

Perlite deposits in the study area are exposed in the Nathrop Volcanics on Ruby Mountain, at the extreme northwestern corner of the study area, and above Cottonwood Creek, about 2.5 mi southeast of Ruby Mountain. The Ruby Mountain deposit, an identified resource which has value for industrial uses, contains at least 540,000 short tons of perlite. An additional 2.5 million short tons of perlite could be present, assuming the downdip continuity of the Ruby Mountain deposit to the Arkansas River. About 30 percent of this additional perlite would be inside the study area. The deposit above Cottonwood Creek is considered too small to be a resource.

Spessartine garnet, topaz, and black obsidian nodules (called Apache tears) from Ruby Mountain are collected for mineral specimens; black tourmaline crystals from simple pegmatites are also collected in the study area.

Small quantities of sand and gravel are present in most of the washes and dry gulches of the study area and along the Arkansas River. Sufficient quantities of sand and gravel are available outside the study area, closer to local markets, to satisfy current local needs.

This investigation covered the Browns Canyon Wilderness Study Area and adjacent areas to provide necessary background information to evaluate the identified 


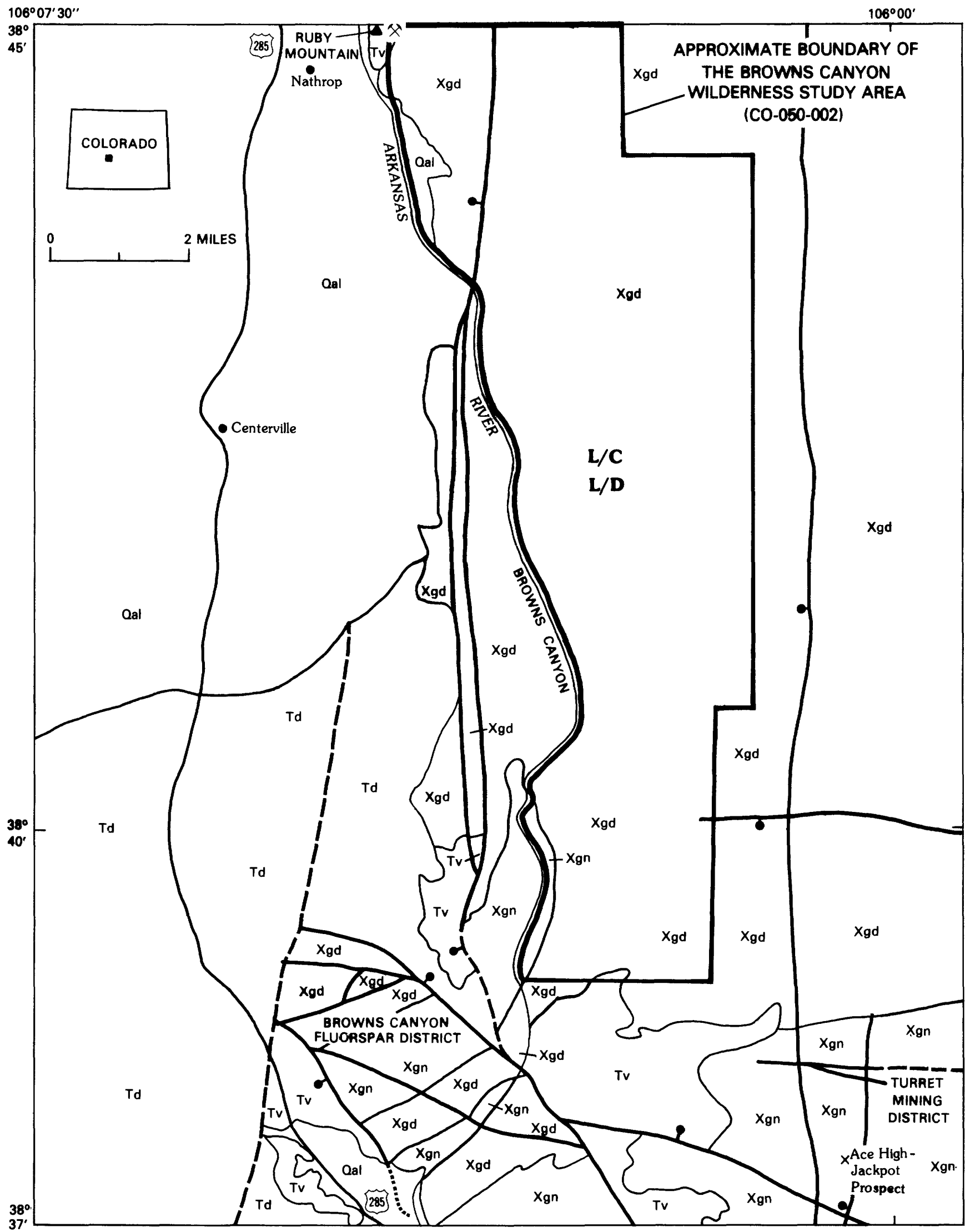

Figure 1 (above and facing page). Map showing mineral resource potential and generalized geology of the Browns Canyon Wilderness Study Area, Chaffee County, Colorado (geology modified from Scott and others, 1975).

C2 Mineral Resources of Wilderness Study Areas-South-Central Colorado 


\section{EXPLANATION}

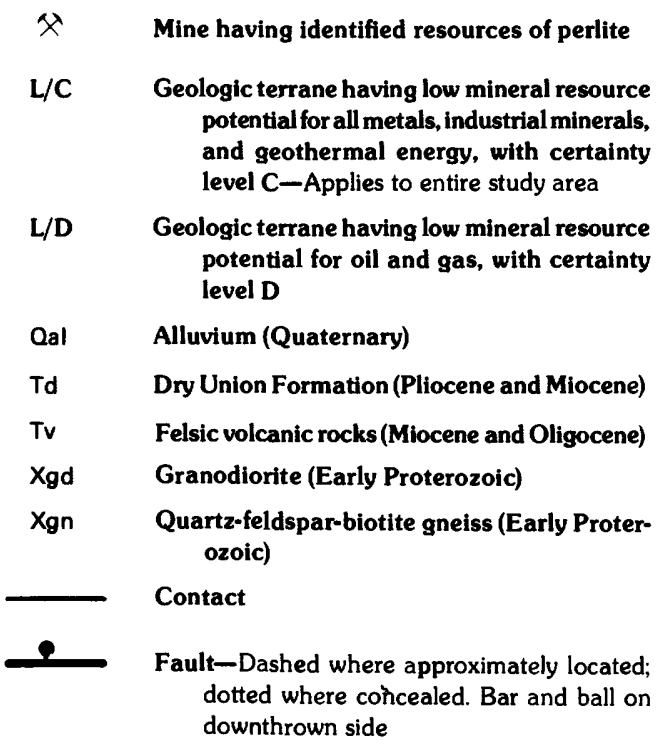

mineral resources and to assess the potential for undiscovered mineral resources. The USBM (U.S. Bureau of Mines) collected 58 rock samples from prospects, pegmatites, and perlite occurrences in or near the study area. Chip samples were taken across altered and mineralized structures; grab or select samples were taken of mine-dump material. The USGS (U.S. Geological Survey) investigation included a review of previous geological studies, collection and analysis of stream-sediment samples from 123 sites from the study area and proximity, and a search for mines, prospects, and mineralized areas. Analyses of the geochemical samples indicated no areas with significant concentrations of metals in the study area. Geological, geochemical, and geophysical characteristics of the study area indicate a low mineral resource potential for mineral and geothermal resources, and no potential for oil and gas resources.

\section{INTRODUCTION}

In 1983 and 1984 the USGS and the USBM studied 6,614 acres of the Browns Canyon Wilderness Study Area (CO-050-002), Chaffee County, Colorado. The study of this acreage was requested by the BLM (U.S. Bureau of Land Management). In this report the studied area is called the "wilderness study area" or simply the "study area."

The Browns Canyon Wilderness Study Area, about $6 \mathrm{mi}$ south of Buena Vista and $7 \mathrm{mi}$ northwest of Salida (fig. 2), includes rugged, mountainous terrain with elevations ranging from about $7,400 \mathrm{ft}$ (feet) along the Arkansas River to $9,082 \mathrm{ft}$ in the eastern part of the study area. Many intermittent streams drain the study area,

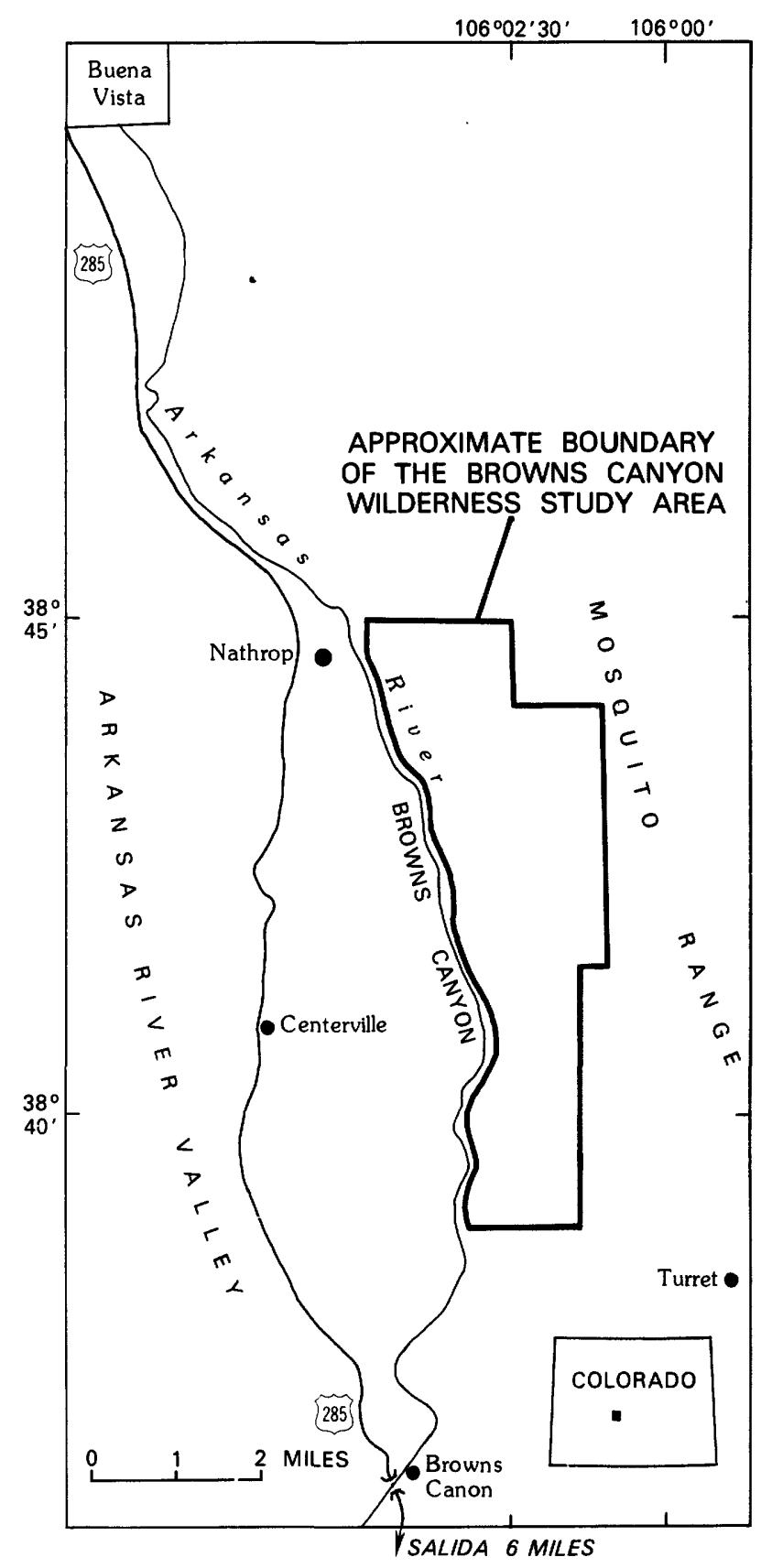

Figure 2. Index map showing the location of the Browns Canyon Wilderness Study Area, Chaffee County, Colorado.

flowing into the Arkansas River. The study area is accessible by foot from dirt roads to the east, and by boat along the Arkansas River from the west.

\section{Investigation by the U.S. Bureau of Mines}

Prior to field investigation in 1983 and 1984, USBM geologists reviewed published and unpublished literature for information regarding the Browns Canyon Wilderness Study Area. Local residents and personnel from the 
USBM, USGS, and BLM were interviewed regarding minerals in and near the study area. BLM records in Denver and Salida, and county records in Salida were examined for locations of mining claims and mineral leases in and near the wilderness study area.

Mines, prospects, and pegmatite and perlite outcrops in and within $1 \mathrm{mi}$ of the study-area boundary were mapped and sampled. Chip samples were taken across altered and mineralized structures; grab or select samples were taken of mine-dump material. A total of 58 samples was collected. Except for four perlite and tuff samples, which were sent to The Perlite Corp. (Aston, Penn.) for special testing, all samples were analyzed for gold and silver by fire assay, and by semiquantitative opticalemission spectrographic methods for 40 elements. Various other analyses were performed on selected samples to determine concentrations of specific suspected elements. Chemical analysis was used to determine fluorine content. Atomic-absorption spectrophotometry was used to determine copper, lead, and zinc, fluorometry was used for uranium, and X-ray fluorescence was used for tungsten. X-ray diffraction was used to determine montmorillonite. These analyses were performed by the USBM Reno Research Center, Reno, Nev. (See Zelten, 1985.)

Four samples of perlite and tuff from the Nathrop Volcanics were expanded and tested by The Perlite Corp. to determine their quality and suitability for industrial uses. The samples were crushed and screened to -30 to -50-mesh, then expanded in a laboratory perlite expander at standard settings with both no preheating and after preheating at $300^{\circ} \mathrm{F}$ and $600^{\circ} \mathrm{F}$. The density of the resulting expanded product was used to determine suitability for industrial uses.

\section{Investigation by the U.S. Geological Survey}

In June and July 1984, the USGS conducted field investigations to assess the potential for undiscovered mineral resources of the Browns Canyon Wilderness Study Area. This investigation included a field check of the previous geological mapping and field studies, a stream-sediment geochemical survey, and an examination of mineralized and altered areas.

The geology and known mineral deposits of the Poncha Springs NE quadrangle, which includes the wilderness study area, were described by Van Alstine (1969). A geologic map at 1:24,000 scale is included in Van Alstine's publication. Scott and others (1975) also described the geology of the wilderness study area; a 1:62,500-scale geologic map accompanies their report. The geologic maps in this report (fig. 1, pl. 1) are modified compilations of these previous maps. Mineral resource potential was classified according to the system of Goudarzi (1984) (see inside front cover of this report).
Acknowledgments.-We appreciate the work done by M. S. Allen, R. C. Davies, and P. K. Mowinckel, who assisted in the field study, and D. E. Detra and J. M. Motooka for their analyses of the geochemical samples.

\section{APPRAISAL OF IDENTIFIED RESOURCES By Jeanne E. Zelten, U.S. Bureau of Mines}

\section{Mining and Mineral-Exploration Activity}

The Browns Canyon Wilderness Study area is not included in any mining district. The Browns Canyon fluorspar district, about $\mathbf{0 . 2 5} \mathrm{mi}$ southwest of the study area (parts of secs. 22, 23, 26, 27, and 34, T. 51 N., R. $8 \mathrm{E}$.), has been one of the principal fluorspar mining districts in the United States (Van Alstine, 1976). The fluorspar was discovered in the early 1920's, and about 130,000 short tons were recovered between 1927 and 1949 . Two of four flotation mills previously in operation in the district still stand but are in disrepair. Fluorspar deposits are large and mine workings were extensive. According to Van Alstine (1969), estimated resources of the district are about 2 million short tons of ore, containing at least 15 percent fluorspar. The faults along which the fluorspar occurs trend northwest and dip southwest. (See Van Alstine, 1969.) No surface evidence of fluorspar was observed in the study area by either Van Alstine or the USBM; the mineralized structures studied by Van Alstine do not trend toward the study area.

Since the mid-1800's, copper, gold, silver, iron, and pegmatite minerals have been mined from Early Proterozoic gneisses and schist, skarns, and complex and zoned pegmatites, and along fault zones in the Turret mining district, southeast of the study area. The district is centered around Turret, which is about $2 \mathrm{mi}$ eastsoutheast of the study area (parts of secs. 27, 28, 29, 32, 33, and 34, T. 51 N., R. 9 E.). More than 5,700 lb (pounds) of copper, $42 \mathrm{oz}$ (ounces) of gold, and $100 \mathrm{oz}$ of silver were recovered; unknown quantities of iron, beryl, mica, and rare earths also were mined. Proterozoic granodiorite and simple pegmatites in the Browns Canyon Wilderness Study Area are not related to the mineralized structures in the Turret district. (See unpub. USBM data, Denver, Colo.; Del Rio, 1960; Eckel, 1961; Vanderwilt, 1947.)

Simple pegmatites and quartz veins in and near the study area have been prospected for quartz, feldspar, and other mineral specimens, chiefly black tourmaline crystals as large as 1 in. (inch) in diameter. Small quartzite occurrences within $1 \mathrm{mi}$ east of the study area were quarried in 1961-62 for use in aggregate and as decorative stone. Van Alstine (1969) described a vermiculite deposit of unspecified dimensions in the study area (SW $1 / 4 \mathrm{SW}^{1 / 4} \mathrm{sec}$. 29, T. 15 S., R. 77 W.). He reported that the deposit 
was exposed by a shaft in a gneiss pendant in the granodiorite. This deposit was not located during the USBM study.

Gravels along the Arkansas River and its western tributaries have yielded small quantities of placer gold (less than $50 \mathrm{oz}$ ) since the turn of the century (unpub. USBM data, Denver, Colo.; Van Alstine, 1969). Most of the placer prospecting was in Tertiary and Holocene sedimentary rocks and sediments in drainages west of the Arkansas River. Two ounces of gold were recovered in 1932 and $2 \mathrm{oz}$ in 1939 from placer mines in gravels along the western side of the Arkansas River in Browns Canyon (unpub. USBM data, Denver, Colorado; Vanderwilt, 1947).

All or parts of 17 unpatented lode- or placer-mining claims are in the study area, and many patented and unpatented lode and placer claims have been located within $2 \mathrm{mi}$ of the boundary. Prospects examined inside the study area are on quartz veins, simple pegmatites, dikes, and shear zones in the granodiorite and in the Nathrop Volcanics. Veins, dikes, and shear zones in Proterozoic gneiss and granodiorite within $1 \mathrm{mi}$ south and east of the study area were prospected in the early 1900's for gold, tungsten, silver, copper, lead, zinc, and iron. Production records were not located for any of these prospects.

\section{Geothermal Resources}

Two warm springs and a warm-water well are in the Browns Canyon thermal area, centered about $1 \mathrm{mi}$ southwest of the study area and roughly coincident with the Browns Canyon fluorspar district (fig. 3). Water temperatures ranged from about $73^{\circ}$ to $81^{\circ} \mathrm{F}$. The thermal area occurs where Proterozoic granitic and metamorphic rocks are in fault contact with Tertiary igneous and sedimentary rocks. All of the springs appear to be fault controlled. (See Pearl, 1979.) Pearl noted, "If these springs are part of one large system, the reservoir may be too deep to be reached economically." The faults do not trend toward the study area, and no thermal springs have been identified there.

Parts of secs. 21, 22, 27, and 34, T. 51 N., R. 8 E., were covered by a geothermal lease in 1975 . There are no records of development work in the area, and the lease was terminated in 1981 .

\section{Oil and Gas}

There is no record or evidence of oil or gas exploration or drilling in or near the study area. An oil and gas lease application (C 34113, fig. 3), consisting of five separate tracts, is $1 \mathrm{mi}$ to the north and northwest. Spencer (1983) rated the region containing the study area as having no petroleum potential because it is underlain by Proterozoic rocks that have no potential for the occurrence of sealed structures or stratigraphic traps.

\section{Appraisal of Sites Examined}

Nonmetallic commodities and minerals are present in the study area. Perlite has been mined on a small scale from the Nathrop Volcanics. Perlite, a glassy volcanic rock of rhyolitic composition, which contains from 2 to 5 percent combined water (Bates, 1969), has resource value for industrial uses. When crushed to uniform size and heated rapidly in a stationary vertical or a rotary horizontal furnace, perlite expands into light cellular particles as much as 20 times its original volume. Expanded perlite has low bulk density, large surface area, low thermal conductivity, high fire resistance, and low sound transmission, and is chemically inert. All of these characteristics make it useful for lightweight concrete and plaster aggregate, insulation, filter aids, soil conditioners, and many other uses. (See Bates, 1969; Benton, 1984; Chesterman, 1975.) Garnet, topaz, Apache tears obsidian, and tourmaline specimens have been and continue to be collected from the Nathrop Volcanics and from pegmatites in the study area. Sand and gravel in the area could be used for construction purposes.

\section{Perlite and Associated Rocks}

Two perlite deposits are in the northern part of the study area. The Ruby Mountain deposit is in a 500 -ftthick sequence of the Oligocene Nathrop Volcanics, which comprise rhyolite, perlite, and an ash-flow tuff, and overlie Proterozoic granodiorite. Perlite also occurs in a remnant of the Nathrop Volcanics above Cottonwood Creek (NW1/4 sec. 29, T. 15 S., R. 77 W.) (See Van Alstine, 1969.)

\section{Ruby Mountain Deposit}

An identified resource of black and gray perlite about $100 \mathrm{ft}$ thick underlies a gray, banded rhyolite flow on Ruby Mountain. The rhyolite, which caps and forms the western side of Ruby Mountain, is about $300 \mathrm{ft}$ thick, dips $50-70^{\circ}$ west, and contains abundant vesicles and lithophysae. The perlite dips about $40^{\circ} \mathrm{W}$. and contains variable amounts of obsidian nodules as much as about $3 / 16$ in. in diameter. About 1,600 short tons of perlite were extracted previously from an opencut in ash-flow tuff (Zelten, 1985). No information was located as to when this work was done or if any testing was performed on the material.

A stratigraphically lower unit of white and lightgray ash-flow tuff, about $100 \mathrm{ft}$ thick, dipping about $30^{\circ} \mathrm{W}$., and containing perlite and other gray inclusions, 


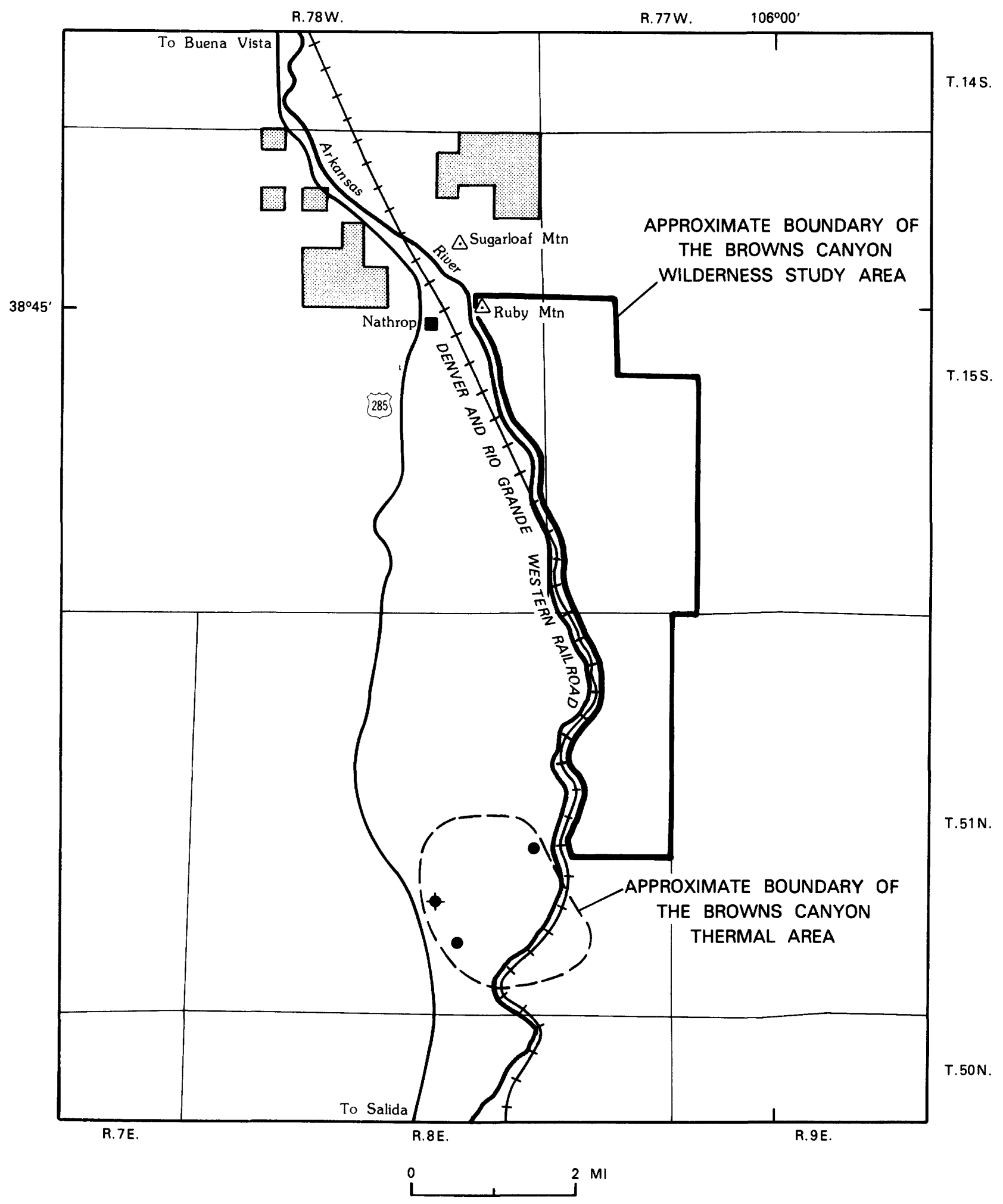

EXPLANATION

Area of oil and gas lease application C 34113

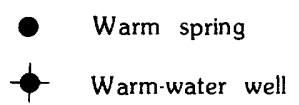

Figure 3. Map showing oil and gas lease application and Browns Canyon thermal area near the Browns Canyon Wilderness Study Area, Colorado. Lease application data from U.S. Bureau of Land Management, 1984. Thermal-area data modified from Pearl (1979).

C6 Mineral Resources of Wilderness Study Areas-South-Central Colorado 
underlies the black and gray perlite. Blocks of granodiorite as much as $3 \mathrm{ft}$ in diameter are present in the lower part of the flow. The tuff contains volcanic glass and montmorillonite. An estimated 90 short tons of rock were extracted previously from an opencut in this tuff. No information is available as to when this work was done, or if any testing was performed on the material.(See Zelten, 1985.)

At least 540,000 short tons of perlite are present on Ruby Mountain. This tonnage estimate is based on the following measurements: surface length, $1,500 \mathrm{ft}$; width, $50 \mathrm{ft}$ downdip; and thickness, $100 \mathrm{ft}$, all of which would be minable by surface methods. A tonnage factor of $13.9 \mathrm{ft}^{3} /$ ton (cubic feet per ton) was used to convert from volume to weight. An additional 2.5 million short tons of perlite could be present assuming downdip continuity of the deposit $230 \mathrm{ft}$ to the Arkansas River. About 30 percent of this perlite would be inside the study area. (See Zelten, 1985.)

Perlite and ash-flow tuff samples were crushed and screened to prepare a -30 to +50 -mesh fraction for expansibility testing. As determined by The Perlite Corp., the quality of the perlite from the Browns Canyon Wilderness Study Area is adequate for use as plaster and concrete aggregate, filter aid, plaster board, and cryogenics, if preheated to $300^{\circ} \mathrm{F}$. Testing of samples of the ash-flow tuff indicated that the material may be adequate for use as plaster and concrete aggregate, if preheated to $300^{\circ} \mathrm{F}$. The overall density of this material is higher than that of the perlite and limits the usefulness of the expanded product. Expanded material containing considerable amounts of dark-colored specks, or a uniformly off-color expanded product, does not sell well in the United States in competition with clean material, although the color has no effect on the usefulness of the product (The Perlite Corp., written commun., 1985). The expanded perlite samples from Ruby Mountain were light gray, which is not as acceptable a color as white. The above tests are preliminary and useful to determine probable quality, but tests of large volumes of material are needed to establish degree of uniformity and definite uses. (See Zelten, 1985.)

The characteristics of the expanded perlite, together with the accessibility, size, and location of a deposit with respect to local markets, determine the value of the deposit. Perlite is generally mined by open-pit methods. Eighty-six percent of the perlite mined in the United States comes from New Mexico, from mines producing about 200,000 tons per year. Colorado's production is from the Rosita deposit, about $50 \mathrm{mi}$ southeast of the study area. The Rosita perlite is $40-75 \mathrm{ft}$ thick; about 20 million tons of reserves were present in 1956. (See Harben and Bates, 1984; Jaster, 1956; Pettifer, 1981.)

The perlite deposit at Ruby Mountain is small but has resource value for industrial uses. Ruby Mountain is easily accessible from U.S. Highway 285 and the Denver and Rio Grande Western Railroad by a well-maintained dirt road. A jeep trail up the eastern side of the mountain provides access directly to the deposit. The satisfactory quality, good accessibility, and size make it amenable to development.

\section{Cottonwood Creek Deposit}

A remnant of the Nathrop Volcanics is exposed for about $200 \mathrm{ft}$ along a hillside above Cottonwood Creek. Rhyolite, perlite, and an ash-flow tuff, similar to the sequence found on Ruby Mountain, are exposed in a $25 \mathrm{ft}$ by $6 \mathrm{ft}$ by $7 \mathrm{ft}$ opencut. The perlite zone here is about $10 \mathrm{ft}$ thick but is mostly black and gray volcanic glass with perlite bands and streaks several inches wide. Clay and granodiorite inclusions are prevalent in the perlite. The ash-flow tuff is about $12 \mathrm{ft}$ thick. Because of the small size and apparent poor quality of this deposit, perlite expansibility tests were not conducted and no resource estimates were made. This deposit is seasonally accessible by jeep trails from the eastern side of the study area. The poor quality, poor accessibility, and small size are factors decreasing the possibility of economic development of this deposit.

\section{Rock and Mineral Specimens}

Garnet, topaz, Apache tears, and tourmaline are collected for specimens from the Nathrop Volcanics on Ruby Mountain and from pegmatites in the study area.

Abundant lithophysae in the rhyolite that caps Ruby Mountain contain clear, euhedral spessartine garnet crystals, averaging $1 / 32$ to $1 / 16$ in. in diameter, and topaz crystals, as much as $1 / 4$ in. in diameter, both of which are collected for specimens. Seaman (1979) identified microscopic native-gold blebs, garnet, hematite, and pseudobrookite (a titanium-iron oxide) in the lithophysae. Van Alstine (1969) identified garnet, topaz, sanidine, quartz, tridymite, opal, calcite, magnetite, and hematite in vesicles and lithophysae of the rhyolite. Garnet, hematite, and topaz were noted in lithophysae by USBM geologists.

Black obsidian pellets as large as $3 / 16$ in. in diameter are abundant in the perlite on Ruby Mountain. These nodules, or marekanites, are often called Apache tears and have value as specimens.

Black tourmaline crystals as large as 1 in. in diameter have been collected for specimens from simple pegmatites in the northern part of the study area.

\section{Sand and Gravel}

Sand and gravel occur in most of the washes and dry gulches throughout the study area and along the Arkansas River. Extensive Quaternary alluvial deposits of sand and gravel currently are being quarried at several 
locations about 2 mi west of the study area, near U.S. Highway 285 . These deposits are sufficient to satisfy current local needs.

\section{ASSESSMENT OF POTENTIAL FOR UNDISCOVERED RESOURCES}

\author{
By Anne M. Leibold, Ronald G. Worl \\ and Ronny A. Martin,
}

U.S. Geological Survey

\section{Geology}

The following descriptions of geologic setting and rock units were modified from Van Alstine (1969) and Scott and others (1975).

\section{Geologic Setting}

The Browns Canyon Wilderness Study Area lies on the western flank of the Mosquito Range, adjacent to the Arkansas River valley (fig. 2). Regional basin-and-rangestyle block faulting along a general northern trend during the Miocene and Pliocene probably formed the Arkansas River valley structural depression. This graben is considered to be a northern extension of the Rio Grande rift and is now filled with thick sediments (Epis and others, 1980; Van Alstine, 1969). Proterozoic metamorphic and igneous rocks, Tertiary volcanic and sedimentary rocks, and Quaternary alluvium are exposed in the vicinity of the study area (pl. 1) (Van Alstine, 1969; Scott and others, 1975). North- and northwest-trending normal faults are the predominant local geologic structures. Van Alstine (1969) suggested that some of these faults were active in Proterozoic as well as in early and late Tertiary time.

The Browns Canyon fluorspar district, directly southwest of the wilderness study area, is localized in a horst. Normal faults on the northeastern and southwestern sides of the horst juxtapose Proterozoic rocks and Oligocene volcanic and Pliocene and Miocene sedimentary rocks. The major fluorspar deposits are localized along the faults bounding the southwestern side of the horst and along smaller northeast- and northwesttrending faults and joints that transect the horst.

The Ace High-Jackpot sulfide prospect (fig. 1) lies in a lenticular body of Early Proterozoic hornblende gneiss (unit $\mathrm{Xh}, \mathrm{pl} .1$ ) bounded by two north-trending faults in the NW $1 / 4$ sec. 32, T. 51 N., R. 9 E. This prospect is in the western part of the Turret mining district, centered about 2 mi southeast of the wilderness study area. This district includes many mines and prospects in secs. 28, 29, 31, and 32 (T. 51 N., R. 9 E.). Most notable are the Gold Bug and Golden Wonder mines characterized by gold in fault-controlled quartz veins, and the Independence and Turret deposits, which were described as copper-zinc skarns (Heinrich, 1981; Lindgren, 1908).

\section{Description of Rock Units}

Early Proterozoic metamorphic rocks, exposed in the southwestern part of the study area, include hornblende gneiss (unit Xh, pl. 1) and banded quartz-feldsparbiotite gneiss (unit Xgn, pl. 1); they are intercalated in places and are interpreted as sedimentary in origin. The hornblende gneiss is a dark-green to black, fine to medium-grained foliated rock. The banded gneiss is a fine- to medium-grained foliated rock with light- to darkcolored bands.

Early Proterozoic igneous rocks include a granodiorite batholith (unit Xgd), dated at about 1,700 m.y. (million years), which underlies most of the study area (Van Alstine, 1969). The granodiorite is mottled gray and white, coarse grained, and foliated near the margins of the batholith. It contains large and small xenoliths of metasedimentary rocks that are foliated parallel to the foliation of the granodiorite and some large pendants of hornblende gneiss and banded gneiss that are also foliated parallel to the foliation of the granodiorite. Early Proterozoic dikes and sills of granite aplite (unit Xa), granite pegmatite (unit Xp), dacite porphyry (unit Xdp), and lamprophyre (unit $\mathrm{Xl}$ ) cut the granodiorite and the metamorphic rocks.

Tertiary volcanic and sedimentary rocks overlie the Early Proterozoic units and are exposed in the northwestern corner of and adjacent to the wilderness study area. The volcanic rocks consist of a rhyodacitic sequence of Oligocene age and a rhyolitic sequence of Oligocene age. The Oligocene rhyodacitic sequence is exposed to the south and west of the wilderness study area. It is composed of medium-gray, flow-banded, porphyritic rhyodacite ash (unit Tr), greenish-gray, clayey, rhyodacite ash (unit $\mathrm{Ta}$ ), and gray, crystal-rich, welded rhyolite ash-flow tuff (unit Tw). The rhyolitic sequence of Oligocene age, the Nathrop Volcanics (unit Tn), is exposed in the northwestern corner of the study area. In descending order, this sequence consists of (1) a gray or light-brown flowbanded rhyolite with lithophysae containing spessartine garnets and topaz; (2) a medium-gray to black perlitic obsidian; and (3) a white-to-pink pumiceous laharic flow. A small remnant of the Nathrop Volcanics is also exposed in sec. 29, T. $15 \mathrm{~S}$., R. $77 \mathrm{~W}$.

Sedimentary rocks adjacent to the wilderness study area include the Browns Canyon Formation (unit $\mathrm{Tb}$ ) of Miocene and Oligocene age, and the Dry Union Formation (unit Td) of Pliocene and Miocene age. The Browns Canyon Formation is a gray to yellowish-brown, welllayered tuffaceous siltstone. The Dry Union Formation consists of poorly consolidated layers of gray clay, silt, 
sand, and gravel. Volcanic lithologies predominate in the gravels, but Precambrian rock fragments are also present.

Quaternary alluvium (unit Qal) is present along the Arkansas River banks and in the Arkansas Valley.

\section{Geochemistry}

A geochemical survey to evaluate the mineral resource potential of the Browns Canyon Wilderness Study Area included the collection and analysis of streamsediment samples and heavy-mineral concentrates from 123 sites in and adjacent to the wilderness study area (pl. 1). The sample density in the wilderness study area averaged 3 samples per square mile. The two known mineralized districts adjacent to the wilderness study area, the Browns Canyon fluorspar district (secs. 22, 23, 26, 27, 34, and 35, T. 51 N., R. 8 E.) and the Turret district (secs. $27,28,29,32,33$, and 34 , T. 51 N., R. 9 E.) were sampled to characterize the geochemical response of these districts and to assist in the recognition of similar mineralized areas within the wilderness study area. In the Turret district, emphasis was placed on characterizing the response of the Ace High-Jackpot prospect in sec. 32. Well-developed drainages in these two mineralized districts were sampled about every $0.25 \mathrm{mi}$. Bulk stream sediments and panned concentrates were collected at each site. Each sample represents a composite collection of stream sediment.

\section{Analytical Methods}

At each sample site about $1.6 \mathrm{~kg}$ (kilograms) of stream sediment were collected from point bars or sections of lower gradient to constitute the bulk samples. This material was dried and sieved to minus- 80 mesh. A $0.5-\mathrm{g}$ (gram) sample was digested in an aqua regia $\left(1 \mathrm{HNO}_{3}: 3 \mathrm{HCl}\right)$ solution, dried by heating, then cooled. The residue was then redissolved in $20 \mathrm{~mL}$ (milliliters) of 20 percent $\mathrm{HCl}$ and warmed on a hot plate. This solution was filtered into a test tube and analyzed by inductively coupled plasma atomic-emission spectroscopy (ICP) (Church, 1981) for $\mathrm{Al}, \mathrm{Ca}, \mathrm{Fe}, \mathrm{Mg}, \mathrm{Ag}, \mathrm{As}, \mathrm{B}, \mathrm{Ba}, \mathrm{Be}, \mathrm{Bi}$, $\mathrm{Ce}, \mathrm{Cd}, \mathrm{Co}, \mathrm{Cr}, \mathrm{Cu}, \mathrm{La}, \mathrm{Mn}, \mathrm{Mo}, \mathrm{Nb}, \mathrm{Ni}, \mathrm{P}, \mathrm{Pb}, \mathrm{Sb}, \mathrm{Sn}$, $\mathrm{Sr}, \mathrm{Ti}, \mathrm{V}, \mathrm{W}, \mathrm{Y}$, and $\mathrm{Zn}$.

To obtain the heavy-mineral concentrates, about 7 $\mathrm{kg}$ of sediment was collected from riffle gravels and screened through a 10-mesh stainless-steel screen at each sample site. The sediment was panned until about 50 percent quartz and feldspar remained in the concentrate. This material was dried, sieved to minus- 30 mesh, and was processed through bromoform (specific gravity 2.85-2.89) and a modified Frantz isodynamic separator ${ }^{1}$ to obtain

${ }^{1}$ Use of trade names in this report is for descriptive purposes only and does not imply endorsement by the U.S. Geological Survey. three fractions: (1) magnetic at $0.25 \mathrm{~A}$ (ampere), (2) magnetic at $1.2 \mathrm{~A}$, and (3) nonmagnetic at $1.2 \mathrm{~A}$. The nonmagnetic fraction was split, ground with a mortar and pestle, and analyzed semiquantitatively for 31 elements (Fe, Mg, Ca, Ti, Mn, Ag, As, Au, B, Ba, Be, Bi, Cd, Co, $\mathrm{Cr}, \mathrm{Cu}, \mathrm{La}, \mathrm{Mo}, \mathrm{Nb}, \mathrm{Ni}, \mathrm{Pb}, \mathrm{Sb}, \mathrm{Sc}, \mathrm{Sn}, \mathrm{Sr}, \mathrm{V}, \mathrm{W}, \mathrm{Y}, \mathrm{Zn}$, $\mathrm{Zr}$, and $\mathrm{Th}$ ) by the six-step optical-emission spectrographic method (Grimes and Marranzino, 1968).

Samples having anomalous metal concentrations were determined and evaluated, primarily using raw-data listings, basic statistics, histograms, single-element plots, and R-mode factor analysis. The purpose was to determine anomalous metal concentrations and to detect element associations that may reflect geologic processes or features, such as underlying lithology, mineralization, and geochemical-dispersion processes. Binocular-microscope examination of the mineralogy of the heavy-mineral concentrates augmented data interpretation. A brief summary of the procedures and conclusions are presented below; however, a complete review of the data and interpretation is available in the files of the USGS.

\section{Results of Survey}

Interpretation of the geochemical data using classical geochemical concepts (Goldschmidt, 1954) and a variety of statistical methods identified no indication of mineralized rock in the wilderness study area.

Minus-80-mesh samples 45, 46, 104, 105, 106, 107, 141 , and 143, from the northern part of the wilderness study area (pl. 1), possess anomalous values for the geochemical association V-Cr-Fe-P-Nb-Co-Ni. These anomalous values probably indicate the high content of magnetite, amphibole, biotite, and monazite in the granodiorite. The amphibole, biotite, and monazite enrichment in this area was also reflected markedly in the panned concentrates, mineralogically and chemically. Samples 45, 46, 48, 104, 105, 106, and 141 contained anomalous values for the geochemical association V-Fe-Cr-Co-Mo.

Heavy-mineral-concentrate samples 43,113 , and 114 , from Green Gulch in the southern part of the study area (pl. 1), contained anomalous concentrations of magnesium. Mineralogical examination revealed a higher than average amphibole and pyroxene content in these samples. Sample 113 also contained an anomalous concentration of tungsten (1,000 ppm or parts per million), and scheelite was noted in this sample. The source of the scheelite is unknown but is believed to be economically insignificant because tungsten values for all other samples in this drainage were near or below the detection limit (100 ppm).

Data from the two known mining districts adjacent to the wilderness study area (the Browns Canyon fluorspar district and the Ace High-Jackpot area of the Turret 
district) showed coherent geochemical signatures. The minus-80-mesh stream-sediment data revealed anomalous concentrations of lead, zinc, copper, barium, and beryllium in samples collected just north of the Browns Canyon fluorspar district (samples 7, 8, 9, 11, 16, and 17). These samples are from the head of an arroyo that drains the Tertiary Dry Union Formation, and from Tertiary volcanic and Early Proterozoic metamorphic rocks at the mouth of the arroyo (pl. 1).

In the heavy-mineral concentrates, the geochemical signature of this area is defined by anomalous concentrations of barium, lanthanum, strontium, and thorium. Barite, identified in these samples, is probably the main source of the barium and strontium anomalies. Felsic volcanic rocks crop out in much of this area, and this lithology may contribute to the high lanthanum and thorium values. In addition, gold flakes were identified in several samples $(4,7,8$, and 10$)$ from this area. The source of the gold is unknown; it may be related to: (1) the Browns Canyon fluorspar mineralization, (2) the Dry Union Formation, or (3) a presently undefined source. Neither gold nor anomalous concentrations of barium, beryllium, copper, lanthanum, lead, strontium, thorium, or zinc were present in samples from the wilderness study area.

Samples from the Ace High-Jackpot prospect area contained anomalous concentrations of lead, copper, molybdenum, tungsten, and zinc (samples 56, 57, 65, 67, $68,69,81,82,100$, and 101). Pyrite, scheelite, and gahnite were identified in several of these samples. High tin values $(500-1,500 \mathrm{ppm})$ in samples $56,81,98$, and 99 coincide with the identification of cassiterite in these samples. Silver was detected in samples $98(20 \mathrm{ppm})$ and 100 $(200 \mathrm{ppm})$. Gold was also detected in sample 98 $(200 \mathrm{ppm})$, and gold flakes were identified microscopically. This sample was collected downstream from several gold mines in the Turret district. None of these geochemical responses was observed in samples from the wilderness study area.

\section{Geophysics}

Geophysical data that include the Browns Canyon Wilderness Study Area and vicinity were interpreted by Case and Sikora (1984). The data consist of a high-level, regional aeromagnetic survey and a regional gravity survey (figs. 4 and 5). The aeromagnetic survey was flown using a total-intensity magnetometer at an elevation of $14,500 \mathrm{ft}$ above sea level with east-west flight lines spaced about $2 \mathrm{mi}$ apart. No gravity-data points are within the study area, but data points are along U.S. Highway 285 west of the wilderness study area at about 1-mi intervals. The aeromagnetic and gravity data delineate regional geological features.

The gravity data show a general density change from the eastern side of the Arkansas Valley ( -250 to
$-270 \mathrm{mGal}$, or milligals) to the western side ( -270 to $-290 \mathrm{mGal}$ ). This density contrast may relate to changes in gross crustal or upper mantle properties (Case and Sikora, 1984).

The gravity data show a strong east-west gradient along the western side of the wilderness study area (fig. 5) that relates to density contrasts caused by faulting, which juxtaposed valley fill against Early Proterozoic rocks along the Rio Grande rift zone. The gravity gradient marks the edge of the rift zone. High magnetic intensity and a steep east-west magnetic gradient north of the wilderness study area suggest that valley fill is juxtaposed against granitic Early Proterozoic rocks. Lower magnetic intensity and the divergence of the magnetic contour pattern across the central part of the study area indicate less magnetic contrast between valley fill and Early Proterozoic rocks and suggest a difference in lithology of either the Proterozoic rocks or the valley-fill material from similar rocks to the north.

Magnetic intensity is low over the Arkansas River valley because of the great depth to basement rock; the thick section of valley fill causes a negative gravity anomaly. A northwest-trending horst that is truncated by the north-trending valley-margin fault was mapped just south of the study area and is expressed by a positive gravity flexure that extends into the Arkansas River valley. Browns Canyon fluorspar deposits are along this trend in a northwest-trending fault, but neither the horst nor the northwest-trending mineralized fault zone have a magnetic expression on the high-level aeromagnetic survey.

\section{Mineral and Energy Resources}

The potential for mineral resources in the Browns Canyon Wilderness Study Area was assessed by comparing geochemical, geophysical, and geological characteristics of the study area with those of nearby mineralized areas. The geological characteristics of the wilderness study area were also compared with those of mineraldeposit models.

Geological and geochemical features of the study area suggest four models for the possible presence of precious- or base-metal deposits: (1) fluorspar and related metals localized along and near major rift faults, (2) basemetal (predominantly copper-zinc) skarns, (3) copper-zinc metamorphosed exhalative deposits, and (4) gold and silver in fault-controlled quartz veins. A brief description of these models and a comparison with geological features of the wilderness study area provide a framework for the assessment of the mineral resource potential for the Browns Canyon Wilderness Study Area.

Chalcedony-fluorspar veins, which make up the Browns Canyon fluorspar district deposits, are localized along steeply dipping northeast-trending faults. These 


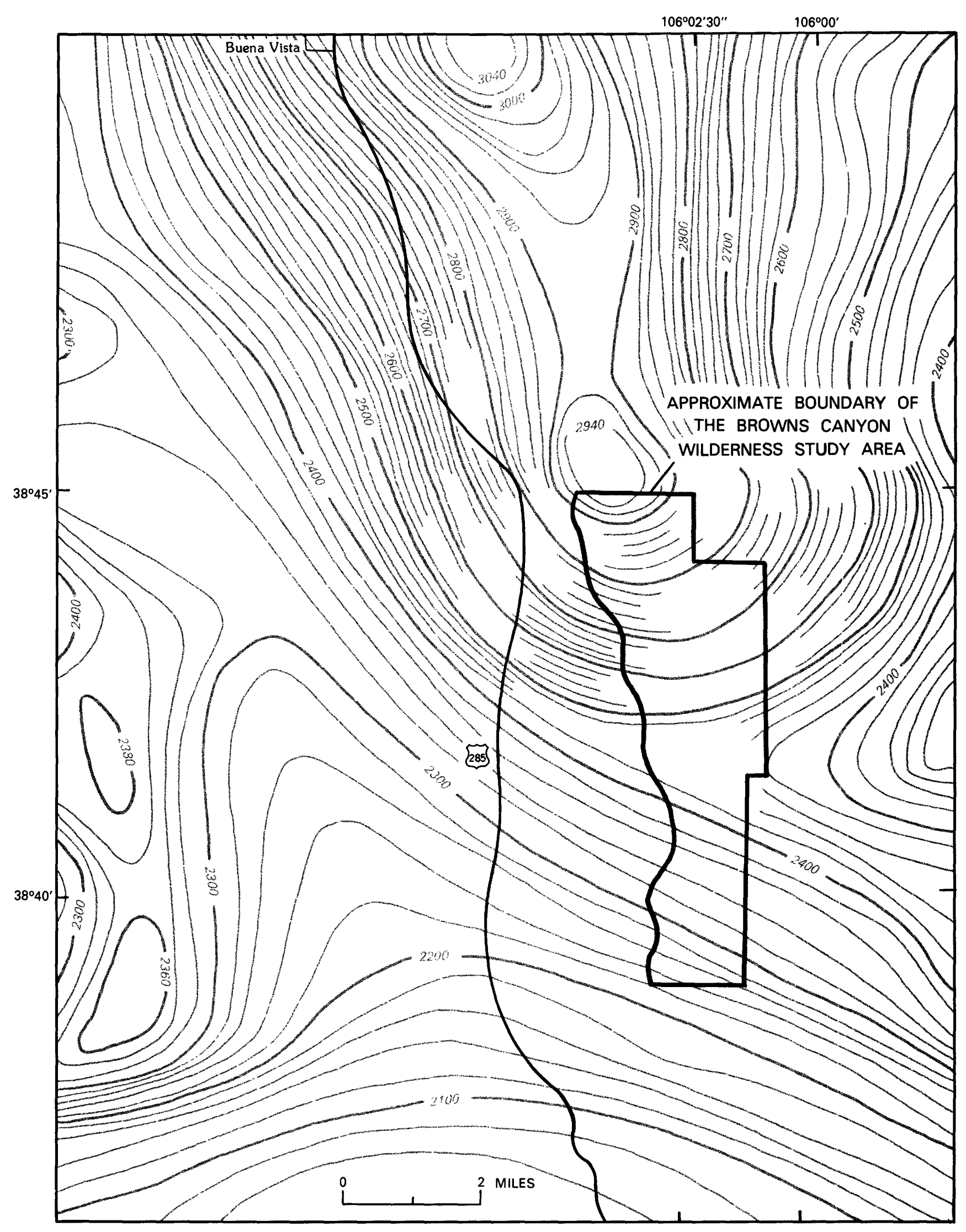

Figure 4. Aeromagnetic contour map of the Browns Canyon Wilderness Study Area, Colorado, and vicinity. Contour intervals, 20 gammas. From Case and Sikora (1984). 


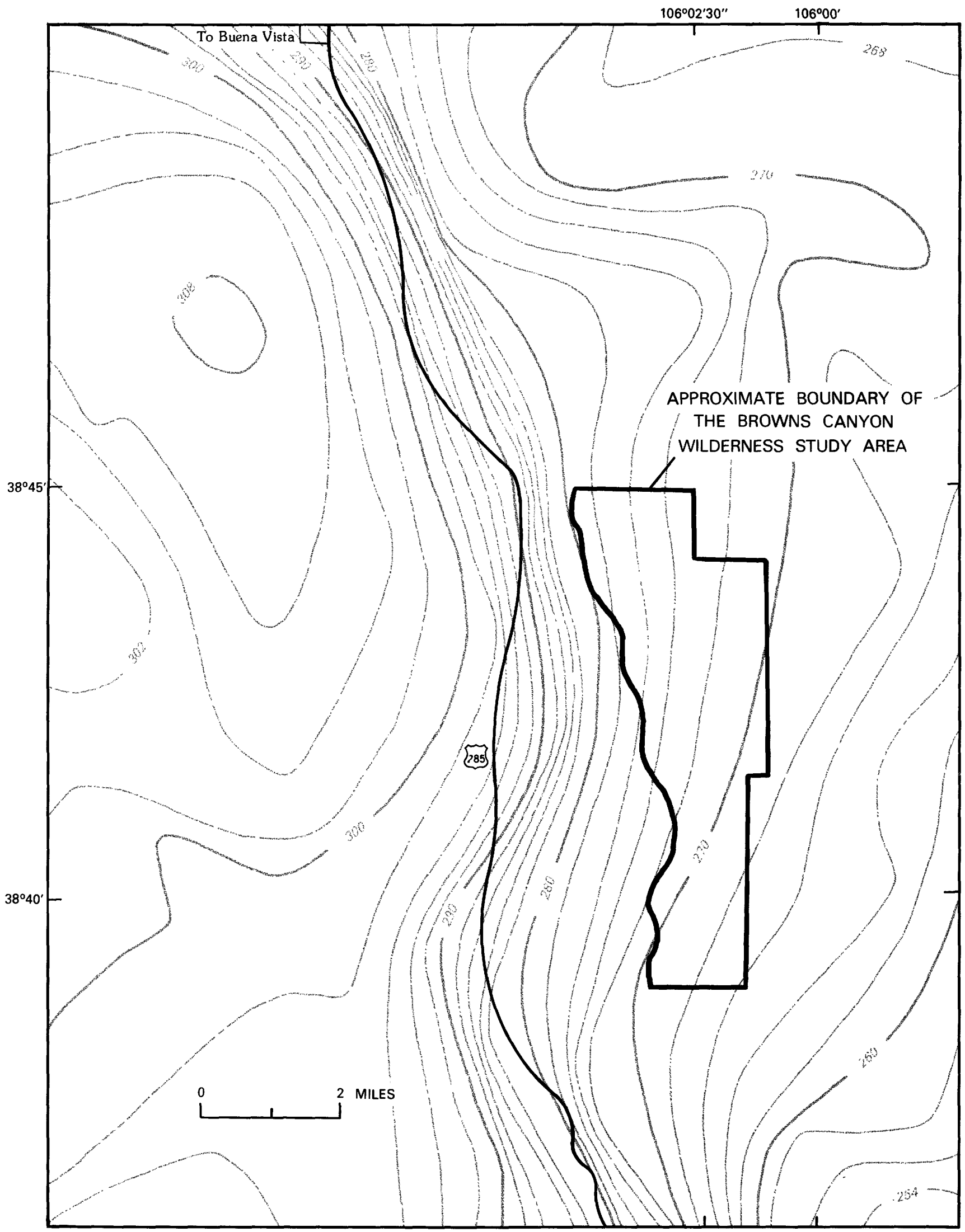

Figure 5. Gravity contour map showing Bouguer anomalies of the Browns Canyon Wilderness Study Area, Colorado, and vicinity. Contour interval, 2 milligals. From Case and Sikora (1984). 
faults bound a horst that brings Proterozoic metamorphic rocks in contact with Oligocene rhyolitic volcanic rocks (pl. 1). Van Alstine (1969) cited evidence for a Tertiary fumarolic hot-springs environment of deposition. Notably, several thermal springs are along faults in this mining district (Barrett and Pearl, 1978). Mineralogical studies of stream-sediment heavy-mineral concentrates from this area generally revealed abundant fluorite.

Van Alstine (1969) suggested that faults along which the fluorspar is localized may extend to the northwest and southeast of the fluorspar district, but they do not transect the wilderness study area. Fluorite similar to that from panned concentrates of the fluorspar district was not observed in samples from the wilderness study area. There is no evidence of geothermal activity or related alteration or mineralization in the Browns Canyon Wilderness Study Area. Therefore, a low mineral resource potential for fluorspar and geothermal resources is assigned to the wilderness study area, with certainty level $\mathrm{C}$.

Heinrich (1981) described the copper-zinc skarns of south-central Colorado as epigenetic disseminatedreplacement deposits in terranes intruded by 1,400 - or 1,700-m.y.-old granitoid plutons. Deposits described by Heinrich (1981) include the Independence and Turret mines and the Ace High-Jackpot prospect in the Turret mining district. He also described the Sedalia mine, once the largest copper mine in Colorado, about $7 \mathrm{mi}$ south of the Browns Canyon Wilderness Study Area (sec. 18, T. 50 N., R. 9 E.). He suggested that host-rock type, normally amphibolite, hornblende gneiss, or biotite gneiss, was a major factor in the localization of the minerals. Faulting through or nearby the deposits is common. Chalcopyrite is ubiquitous; sphalerite and gahnite are common; galena, pyrite, and molybdenite are minor or absent. Two types of deposits have been distinguished: those concordant with metamorphic foliation and layering, and those discordant with metamorphic foliation. Both types are recognized in the Browns Canyon region.

Sheridan and Raymond $(1977,1978)$ described the deposits at the Sedalia mine and several other mines in the Salida area about $8 \mathrm{mi}$ south of the study area as metamorphosed exhalative deposits. They suggested that the presence of metasedimentary and metavolcanic host rocks, the preponderance of concordant textural and structural features, the unusual gangue mineralogy, and the clustering of similar deposits in the Salida region support an exhalative origin for these deposits.

The observed $\mathrm{Pb}-\mathrm{Cu}-\mathrm{Mo}-\mathrm{W}-\mathrm{Zn}$ geochemical signature in the Ace High-Jackpot area probably reflects skarn or metamorphosed exhalative mineralization. A typical mineral assemblage, as described by Heinrich (1981) and Sheridan and Raymond (1977, 1978), was observed in many of the heavy-mineral concentrates. Minerals commonly observed in samples from this area include sillimanite, muscovite, gahnite, and pyrite.
These mineralogical and geochemical signatures were not observed in any samples from the Browns Canyon Wilderness Study Area. The geologic setting favorable for skarn or exhalative deposits, fault-bound hornblende gneiss or biotite gneiss units in granodiorite, is uncommon in the study area. Therefore, the mineral resource potential for copper-zinc deposits in the wilderness study area is low, with certainty level $\mathrm{C}$.

The gold-bearing quartz-vein deposits of the Turret district (Gold Bug and Golden Wonder mines) are localized in north- and east-trending fault zones in granodiorite. An east-trending dike of fine-grained porphyry coincides with the deposits. Native gold, and pyrite and minor amounts of other sulfides were reported from these mines (Bhutta, 1954; Lindgren, 1908). Anomalous gold, silver, copper, molybdenum, lead, and tin concentrations and gold flakes were observed in heavy-mineral concentrates from the drainage below these mines. No similar geochemical response was seen in stream-sediment samples from within the wilderness study area, and prospect pits in the study area do not show evidence of similar mineralization. Therefore, the mineral resource potential for gold is rated low, with certainty level $\mathrm{C}$.

Van Alstine (1969) described several other mineral deposit types in the Browns Canyon area, including placer gold, perlite, quartzite, and vermiculite. The geologic setting is unfavorable for the presence of more than small local concentrations of these commodities in the Browns Canyon Wilderness Study Area. The resource potential for placer gold, quartzite, and vermiculite in the wilderness study area is low, with certainty level C. Perlite deposits have been identified in the study area, but they are small.

Spencer (1983) reported that the Browns Canyon Wilderness Study Area has no potential for oil and gas resources. No favorable reservoir lithologies or structural settings are present in the study area; certainty level is D.

Geologic, geochemical, and geophysical characteristics of the Browns Canyon Wilderness Study Area indicate a low potential for the existence of unidentified mineral resources.

\section{REFERENCES CITED}

Barrett, J. K., and Pearl, R. H., 1978, An appraisal of Colorado's geothermal resources: Colorado Geological Survey Bulletin 39, 224 p.

Bates, R. L., 1969, Geology of the industrial rocks and minerals: New York, Dover Publications, 459 p.

Benton, W. E., 1984, Economics of perlite: American Institute of Mining, Metallurgical, and Petroleum Engineers, Society of Mining Engineers, preprint no. 84-382, 11 p.

Bhutta, M. A., 1954, Geology of the Salida area, Chaffee County, Colorado: Golden, Colorado School of Mines Ph.D. thesis, $173 \mathrm{p}$. 
Case, J. E., and Sikora, R. F., 1984, Geological interpretation of gravity and magnetic data in the Salida region, Colorado: U.S. Geological Survey Open-File Report 84-372, $46 \mathrm{p}$.

Chesterman, C. W., 1975, Perlite, in Industrial minerals and rocks (nonmetallics other than fuels): New York, American Institute of Mining, Metallurgical, and Petroleum Engineers, Inc., p. 927-934.

Church, S. E., 1981, Multi-element analysis of fifty-four geochemical reference samples using inductively coupled plasma-atomic emission spectrometry: Geostandards Newsletter, v. 5, p. 33-160.

del Rio, S. M., compiler, 1960, Mineral resources of Colorado, first sequel: Denver, Colorado Mineral Resources Board, $763 \mathrm{p}$.

Eckel, E. B., 1961, Minerals of Colorado-A 100-year record: U.S. Geological Survey Bulletin 1114, 399 p.

Epis, R. C., Scott, G. R., Taylor, R. B., and Chapin, C. E., 1980, Summary of Cenozoic geomorphic, volcanic and tectonic features of central Colorado and adjoining areas, in Kent, H. C., and Porter, K. W., eds., Colorado geology: Rocky Mountain Association of Geologists Symposium, Denver 1980, p. 135-156.

Goldschmidt, V. M., 1954, Geochemistry: Oxford, England, Oxford University Press, 730 p.

Goudarzi, G. H., compiler, 1984, Guide to preparation of mineral survey reports on public lands: U.S. Geological Survey Open-File Report 84-787, 42 p.

Grimes, D. J., and Marranzino, A. P., 1968, Direct-current arc and alternating-current spark emission spectrographic field methods for the semiquantitative analysis of geologic materials: U.S. Geological Survey Circular 591, 6 p.

Harben, P. W., and Bates, R. L., 1984, Perlite, in Geology of the nonmetallics: New York, Metal Bulletin Inc., p. 69-76.

Heinrich, E. W., 1981, Precambrian tungsten and copper-zinc skarn deposits of south-central Colorado: Colorado Geological Survey Resource Series 21, 115 p.

Jaster, M. C., 1956, Perlite resources of the United States: U.S. Geological Survey Bulletin 1027-I, p. 375-403.
Lindgren, Waldemar, 1908, Notes of the copper deposits in Chaffee, Fremont, and Jefferson Counties, Colorado: U.S. Geological Survey Bulletin 340, p. 116-175.

Pearl, R. H., 1979, Colorado's hydrothermal resource basean assessment: Colorado Geological Survey, Department of Natural Resources, Resource Series 6, 144 p.

Pettifer, Lee, 1981, Perlite-diversification the key to overall expansion: Industrial Minerals, no. 171, p. 55-75.

Scott, G. R., Van Alstine, R. E., and Sharp, W. N., 1975, Geologic map of the Poncha Springs quadrangle, Chaffee County, Colorado: U.S. Geological Survey Miscellaneous Field Studies Map MF-658, scale 1:62,500.

Seaman, D. E., 1979, Gold in rhyolite at Nathrop, Colorado: Rocks and Minerals, v. 54, no. 3, p. 108-109.

Sheridan, D. M., and Raymond, W. H., 1977, Preliminary data on some Precambrian deposits of zinc-copper-lead sulfides and zinc spinel (gahnite) in Colorado: U.S. Geological Survey Open-File Report 77-607, 27 p.

1978, Stratabound Precambrian zinc-copper deposit at the Sedalia mine, Chaffee County, Colorado, in Shawe, D. R., ed., Guidebook on fossil fuels and metals, eastern Utah and western-southwestern-central Colorado: Colorado School of Mines Professional Contributions 9, p. $146-150$.

Spencer, C. W., 1983, Petroleum potential of wilderness lands in Colorado, in Miller, B. M., ed., Petroleum potential of wilderness lands in the Western United States: U.S. Geological Survey Circular 902-E, 8 p.

Van Alstine, R. E., 1969, Geology and mineral deposits of the Poncha Springs NE quadrangle, Chaffee County, Colorado: U.S. Geological Survey Professional Paper 626, 52 p.

1976, Continental rifts and lineaments associated with major fluorspar districts: Economic Geology, v. 71, no. 6, p. 977-987.

Vanderwilt, J. W., 1947, Mineral resources of Colorado: Denver, Colorado Mineral Resources Board, 547 p.

Zelten, J. E., 1985, Mineral resources of the Browns Canyon Wilderness Study Area (CO-050-002), Chaffee County, Colorado: U.S. Bureau of Mines Open File Report MLA 70-85, 36 p. 
GEOLOGIC TIME CHART

Terms and boundary ages used by the U.S. Geological Survey, 1986

\begin{tabular}{|c|c|c|c|c|c|}
\hline EON & ERA & \multicolumn{2}{|c|}{ PERIOD } & $\mathrm{EPOCH}$ & $\begin{array}{c}\text { BOUNDARY AGE } \\
\text { IN } \\
\text { MILLION YEARS }\end{array}$ \\
\hline \multirow{17}{*}{ Phanerozoic } & \multirow{7}{*}{ Cenozoic } & \multirow{2}{*}{\multicolumn{2}{|c|}{ Quaternary }} & Holocene & - 010 \\
\hline & & & & Pleistocene & \\
\hline & & \multirow{5}{*}{ Tertiary } & \multirow{2}{*}{$\begin{array}{l}\text { Neogene } \\
\text { Subperiod }\end{array}$} & Pliocene & \\
\hline & & & & Miocene & \\
\hline & & & \multirow{3}{*}{$\begin{array}{l}\text { Paleogene } \\
\text { Subperiod }\end{array}$} & Oligocene & \\
\hline & & & & Eocene & \\
\hline & & & & Paleocene & \\
\hline & \multirow{3}{*}{ Mesozoic } & \multicolumn{2}{|c|}{ Cretaceous } & $\begin{array}{l}\text { Late } \\
\text { Early }\end{array}$ & -96 \\
\hline & & \multicolumn{2}{|c|}{ Jurassic } & $\begin{array}{c}\text { Late } \\
\text { Middle } \\
\text { Early }\end{array}$ & -138 \\
\hline & & \multicolumn{2}{|c|}{ Triassic } & $\begin{array}{c}\text { Late } \\
\text { Middle } \\
\text { Early }\end{array}$ & 205 \\
\hline & \multirow{7}{*}{ Paleozoic } & \multicolumn{2}{|c|}{ Permian } & $\begin{array}{l}\text { Late } \\
\text { Early }\end{array}$ & $\sim 240$ \\
\hline & & \multirow{2}{*}{$\begin{array}{c}\text { Carboniferous } \\
\text { Periods }\end{array}$} & Pennsylvanian & $\begin{array}{l}\text { Late } \\
\text { Middle } \\
\text { Early }\end{array}$ & \\
\hline & & & Mississippian & $\begin{array}{l}\text { Late } \\
\text { Early }\end{array}$ & 000 \\
\hline & & \multicolumn{2}{|c|}{ Devonian } & $\begin{array}{l}\text { Late } \\
\text { Middle } \\
\text { Early }\end{array}$ & 110 \\
\hline & & \multicolumn{2}{|c|}{ Silurian } & $\begin{array}{c}\text { Late } \\
\text { Middle } \\
\text { Early }\end{array}$ & 40 \\
\hline & & \multicolumn{2}{|c|}{ Ordovician } & $\begin{array}{l}\text { Late } \\
\text { Middle } \\
\text { Early }\end{array}$ & 405 \\
\hline & & \multicolumn{2}{|c|}{ Cambrian } & $\begin{array}{l}\text { Late } \\
\text { Middle } \\
\text { Early }\end{array}$ & 500 \\
\hline \multirow{3}{*}{ Proterozoic } & Late Proterozoic & & & & se \\
\hline & Middle Proterozoic & & & & \\
\hline & Early Proterozoic & & & & 104 \\
\hline \multirow{3}{*}{ Archean } & Late Archean & & & & 2500 \\
\hline & Middle Archean & & & & \multirow{2}{*}{3400} \\
\hline & Early Archean & & & & \\
\hline
\end{tabular}

'Rocks older than $570 \mathrm{~m}$.y. also called Precambrian, a time term without specific rank.

${ }^{2}$ Informal time term without specific rank. 
